\title{
Analisis Implementasi Pembelajaran Luring Menjadi Daring Saat Pandemi Covid-19 Pada Mahasiswa Pendidikan Ekonomi Universitas Ekasakti
}

\author{
Dessyta Gumanti ${ }^{1}$, Serli Diovani Teza $^{2}$, Reni Respita ${ }^{3}$ \\ ${ }^{1}$ Universitas Ekasakti Padang, dessytasays@gmail.com \\ ${ }^{2}$ Universitas Ekasakti Padang, serlidiovani@gmail.com \\ ${ }^{3}$ Universitas Ekasakti Padang, renirespita35@gmail.com
}

\section{DOI}

https://doi.org/10.26740/jupe.v10n1.p70$\underline{77}$

\author{
Article history \\ Received \\ 26 November 2021 \\ Revised \\ 10 December 2021 \\ Accepted \\ 12 December 2021
}

\section{How to cite}

Gumanti, D., Teza, D.D., \& Respita' R. (2021). Analisis Implementasi Pembelajaran Luring Menjadi Daring Saat Pandemi Covid19 Pada Mahasiswa Pendidikan Ekonomi Universitas Ekasakti. Jurnal Pendidikan Ekonomi (JUPE), 10(1), 70-77. https://doi.org/10.26740/jupe.v10n1.p7077

Kata Kunci: Implementasi, pembelajaran daring, kelas digital Keywords: Implementation, online learning, Digital Class Platform

\section{Corresponding author}

Dessyta Gumanti

dessytasays@gmail.com

\begin{abstract}
Abstrak
Penelitian ini bertujuan untuk mengetahui implementasi pembelajaran luring menjadi daring saat pandemi covid-19 pada mahasiswa Pendidikan Ekonomi Universitas Ekasakti. Penelitian ini menggunakan jenis penelitian deskriptif dengan pendekatan kualitatif. Sumber data penelitian ini adalah data primer dan data sekunder. Objek penelitian ini merupakan mahasiswa Program Studi Pendidikan Ekonomi Universitas Ekasakti yang telah melaksanakan pembelajaran daring saat pandemi covid-19. Teknik analisis data menggunakan analisis interaktif. Hasil penelitian menunjukkan bahwa secara keseluruhan implementasi pembelajaran dari luring menjadi daring saat pandemi covid-19 pada mahasiswa Pendidikan Ekonomi Universitas Ekasakti telah berjalan dengan baik namun ada beberapa kendala yang ditemui secara umum yaitu kesiapan mengakses internet yaitu susahnya jaringan internet dan juga kuota internet yang mahal, kesulitan dalam memahami materi, sementara secara khusus dalam penggunaan Platform Kelas Digital masalah yang ditemui yaitu kesulitan mahasiswa untuk login sehingga perkuliahan melalui Platform Kelas Digital sering terkendala.
\end{abstract}

Abstract
This study attempts to evaluate how Ekasakti University's Economic
Education students used offline learning to become online during the
covid-19 pandemic. This research employs a descriptive research
design with a qualitative methodology. The primary and secondary
data sources for this study are primary and secondary data. The subject
of this study is a student in Ekasakti University's Economic Education
Study Program who participated in online learning during the covid-
19 epidemic. Interactive analysis was used in the data analysis
technique. The results showed that the overall implementation of
learning from offline to online for Economic Education students at
Ekasakti University went well during the covid-19 pandemic, but there
were several obstacles encountered in general, including the readiness
to access the internet, namely difficult internet networks and expensive
internet quotas, and difficulties in understanding the material, with the
problem encountered specifically in using the Digital Class Platform.




\section{PENDAHULUAN}

Covid-19 telah menjadi pandemi selama 1,5 tahun belakangan yang awalnya sangat berdampak pada dunia ekonomi, tetapi juga memiliki dampak yang begitu besar bagi pendidikan. Pandemi Covid19 adalah peristiwa menyebarnya penyakit koronavirus 2019 (Bahasa Inggris: Coronavirus disease 2019, disingkat Covid-19) di seluruh dunia untuk semua Negara. Penyakit ini disebabkan oleh koronavirus jenis baru yang diberi nama SARSCoV-2. Wabah Covid-19 pertama kali dideteksi di Kota Wuhan, Hubei, Tiongkok pada tanggal 1 Desember 2019, dan ditetapkan sebagai pandemi oleh Organisasi kesehatan Dunia (WHO) pada tanggal 11 Maret 2020. Kebijakan yang diambil oleh banyak negara termasuk Indonesia dengan meliburkan seluruh aktivitas pendidikan, membuat pemerintah dan lembaga terkait harus menghadirkan alternatif proses pendidikan bagi peserta didik maupun mahasiswa yang tidak bisa melaksanakan proses pendidikan secara langsung pada lembaga pendidikan.

Pemerintah Indonesia pun mengambil kebijakan yang bertujuan untuk memutus rantai penularan pandemi Covid-19. Salah satunya adalah penerapan kebijakan social distancing dan Pemberlakuan Pembatasan Kegiatan Masyarakat (PPKM) dimana warga harus menjalankan seluruh aktivitas di rumah, seperti bekerja, belajar, termasuk dalam melaksanakan ibadah. Pemerintah pusat resmi memperpanjang masa Pemberlakuan Pembatasan Kegiatan Masyarakat (PPKM Darurat) hingga 25 Juli 2021, termasuk untuk Kota Padang, Sumatera Barat. Wali Kota Padang, Hendri Septa sudah mengeluarkan surat edaran untuk menindaklanjuti keputusan perpanjangan masa PPKM Darurat Dalam surat edaran itu dijelaskan, selama PPKM Darurat pelaksanaan kegiatan belajar mengajar di sekolah dilakukan secara online (Padek, 2021)

Selain berdampak pada sektor perekonomian, sektor pendidikan juga turut terkena dampak yang cukup besar. Kegiatan belajar mengajar terpaksa harus dilakukan dalam jarak jauh. Sebagai respon dari ditutupnya sekolah-sekolah dikarenakan pandemi Covid-19, pembelajaran jarak jauh menjadi satu di antara jalan keluar yang ditawarkan oleh pemerintah agar pembelajaran tetap berjalan seperti biasanya (Handayani, Febri \& Surahman, 2021) 2020). Sebanyak 4,2 juta Guru dan Dosen belajar dari rumah terdampak pandemi dan sebanyak 68,8 juta siswa belajar dari rumah(Muhammad, 2020). Akan tetapi, dari kebijakan ini juga banyak pihak yang belum siap untuk melaksankan pembelajaran melalui jarak jauh atau yang dikenal dengan sebutan daring.

Pembelajaran luring dan daring sebenarnya sudah diterapkan dalam pembelajaran, bahkan juga sudah mengkombinasikan antara luring dan daring melalui pembelajaran blended learning dan juga hybrid learning. Bahkan semakin hari pembelajaran daring menjadi lebih relevan dan layak diterapkan dibandingkan luring terkhusus dalam situasi pandemi covid -19 yang membatasi pertemuan tatap muka. Pembelajaran daring adalah sistem belajar tanpa tatap muka secara langsung dengan memanfaatkan komunikasi dan teknologi internet serta dilaksanakan secara online. (Haryadi \& Selviani, 2021) pembelajaran daring menjadi salah satu solusi dalam pelaksanaan pembelajaran di masa pandemi Covid19. Bentuk perkuliahan yang dapat dijadikan solusi dalam masa pandemi covid-19 adalah pembelajaran daring (Sadikin \& Hamidah, 2020). Selama pandemi Covid-19 guru atau dosen dan siswa maupun mahasiswa menyelenggarakan pembelajaran secara daring sesuai dengan arahan Mendikbud dalam mencegah penularan Covid-19 yaitu dengan menerapkan Social Distancing. Pandemi Covid-19 menuntut pendidikan tinggi untuk bisa melakukan penyesuaian dalam penyelenggaraan pendidikan. Salah satunya mengubah metode pembelajaran tatap muka (luring) menjadi daring saat pandemi (Ika, 2020).

Pembelajaran luring artinya adalah bentuk belajar yang dilaksanakan dengan pertemuan fisik secara langsung tanpa bantuan teknologi internet untuk komunikasi. Semuanya berlangsung secara offline dengan melakukan tatap muka di kelas secara langsung. Proses kegiatan belajar yang dilakukan dengan memanfaatkan media atau keaadaan luar jaringan disebut dengan metode luring(Eka p, 2021). Pembelajaran luring merupakan singkatan dari pembelajaran di luar jaringan atau dengan istilah offline, artinya pembelajaran ini tidak lain merupakan pembelajaran konvesional yang sering digunakan oleh guru sebelum adanya pandemic covid 19 akan tetapi ada perubahan tertentu seperti jam belajarnya lebih singkat dan materinya sedikit (Pratama \& Mulyati, 2020).

Mansyur dalam (Chandra et al., 2021) salah satu model pembelajaran efektif ditengah situasi pandemi adalah pembelajaran daring. (Lusiani, 2021) Pembelajaran daring efektif mengatasi kegiatan belajar mengajar yang memungkinan pendidik serta peserta didik berinteraksi melalui kelas virtual yang memiliki akses tidak terbatas ruang serta waktu. Kegiatan belajar mengajar daring bisa menjadikan 
mahasiswa belajar mandiri serta meningkatkan motivasi. Kekurangan pembelajaran daring yakni peserta didik tidak terkontrol dengan baik saat proses pembelajaran. Sinyal internet yang tidak stabil serta tingginya biaya kuota merupakan tantangan tersendiri.

Pembelajaran daring menjadi tantangan bagi dunia pendidikan dengan situasi Indonesia yang memiliki ribuan pulau. Bagaimana teknologi dapat digunakan, bagaimana penyediaan akses internet pada daerah-daerah terpencil dimana barang elektronik tanpa akses internet pun masih menjadi suatu kemewahan. Ini merupakan tantangan bagi semua pihak, saat ini kita harus bekerja keras bersama bagaimana membawa teknologi menjawab permasalahan nyata yang terjadi pada mahasiswa dan pelajar yang kurang beruntung dalam hal ekonomi maupun teknologi yang berada di daerah-daerah terpencil. Bukan hanya kesiapan yang masih perlu dibenahi dari pembelajaran jarak jauh ini, banyak kalangan yang ternyata tidak bisa mengikuti kegiatan belajar mengajar jarak jauh karena terbatasnya kemampuan masyarakat, banyak diantaranya yang tidak memiliki perangakat yang menunjang pembelajaran jarak jauh. Implementasi pembelajaran daring menjadi alternatif yang dapat dijalankan selama masa pandemic Covid 19. Namun kendala berbagai sektor menjadikan pembelajaran daring dirasa sulit untuk dilakukan.

Kendala dalam pembelajaran secara daring ini biasanya karena adanya keterbatasan sarana dan prasarana, kurangnya penguasaan dalam menggunakan komunikasi atau teknologi, jaringan internet/ susah signal, biaya kuota, susah memahami materi yang diberikan guru maupun dosen karena pembelajaran jarak jauh (PJJ), tidak ada interaksi langsung dengan guru maupun dosen, pembelajaran dengan teman saat diskusi menjadi kurang efektif, dan guru maupun dosen juga perlu mempersiapkan bahan materinya dengan matang agar siswa maupun mahasiswa dapat memahami materi yang akan diajarkan dalam pembelajaran daring. Akan tetapi, hal tersebut harus tetap dilakukan sebagai salah satu cara dalam proses pembelajaran (Haryadi \& Selviani, 2021)

Selain terhadang oleh kendala dalam dihadapi dalam pembelajaran daring, disatu sisi pembelajaran daring juga memiliki kelebihan. Adapun beberapa kelebihan dari pembelajaran daring yaitu dapat dilakukan kapanpun waktunya dan dimanapun tempat belajarnya, contohya seperti belajar dapat dilakukan di kamar, ruang tamu dan sebagainya serta waktu yang disesuaikan misalnya pagi, siang, sore atau malam. Selain itu pembelajaran daring juga dapat dijangkau walaupun dengan jarak yang jauh sekalipun, seperti halnya peserta didik tidak harus pergi ke sekolah dahulu untuk belajar mereka berada dimana saja bisa mengakses pembelajaran daring(Putri et al., 2021). (Lusiani, 2021) Faktor yang mendukung kegiatan belajar mengajar daring antara lain handphone, kuota, jaringan internet stabil, beberapa hal tersebut digunakan pendidik secara maksimal untuk mengontrol perkembangan siswa saat kegiatan belajar mengajar daring.

Berdasarkan pemaparan diatas maka perlu dilakukan pengkajian bagaimana implementasi pembelajaran luring menjadi daring dapat dilakukan sebagai upaya alternatif proses kegiatan belajar mengajar selama masa pandemi Covid-19 berlangsung. Hal unik dari kajian ini yang belum banyak dikaji pada beberapa penelitian sebelumnya adalah kajian implementasi pembelajaran daring terkhusus disini membahas mengenai platform Kelas Digital yang digunakan dalam pembelajaran daring disamping menggunakan berbagai aplikasi dan platform yang mendukung kegiatan pembelajaran daring. Hasil kajian ini diharapkan dapat memberikan Gambaran bagaimana implementasi pembelajaran luring menjadi daring saat pandemi Covid-19 pada mahasiswa pendidikan ekonomi Universitas Ekasakti.

\section{METODE PENELITIAN}

Penelitian ini menggunakan metode deskriptif kualitatif. Penelitian ini juga mengkaji bentuk, aktivitas, karakteristik, perubahwan, hubungan, kesamaan dan perbedaannya dengan fenomena lainnya. Peneliti memilih pendekatan kualitatif dengan tujuan mengembangkan teori melalui pengungkapan fakta di lapangan dan kemudian dianalisis secara kualitatif agar temuan-temuan di lapangan dapat dipahami maknanya oleh pihak-pihak terkait penelitian, terutama bagi Program Studi Pendidikan Ekonomi dapat sebagai bahan pertimbangan untuk meningkatkan kualitas pembelajaran terutama pembelajaran pada masa pandemic.

Subjek penelitian yang digunakan dalam penelitian ini adalah seluruh mahasiswa Pendidikan Ekonomi Universitas Ekasakti. Subjek dalam penelitian ini mahasiswa terdiri semester 2, 4 dan semester 6 Program Studi Pendidikan Ekonomi Universitas Ekasakti Padang dengan total jumlah mahasiswa 45 orang dengan rincian mahasiswa semester 2 sebanyak 12 orang, mahasiwa semester 4 sebanyak 15 orang dan mahasiswa semester 6 sebanyak 18 orang. Dalam memilih subjek penelitian, 
peneliti menggunakan teknik sampling purposive. Sampling purposive merupakan "teknik penentuan sampel dengan pertimbangan tertentu" (Sugiyono dalam Putria et al., 2020) Pemilihan subjek tersebut dilatarbelakangi karena tujuan dari penelitian ini yaitu untuk mengetahui implementasi pembelajaran luring menjadi daring saat pandemi covid-19 pada mahasiswa Pendidikan Ekonomi Universitas Ekasakti.

Sumber data dalam penelitian ini adalah data primer dan sekunder. Sumber data primer berupa hasil wawancara dan dokumentasi, sedangkan data sekunder berupa Permendikbud dan Permendiknas. Instrumen penelitian yang digunakan peneliti adalah melalui observasi dan lembar pedoman wawancara yang digunakan untuk memberikan pertanyaan kepada mahasiswa mengenai implementasi pembelajaran luring menjadi daring dalam masa pandemi kemudian peneliti melakukan pengumpulan data, analisis dan membuat kesimpulan. Teknik pengumpulan data pada penelitian ini menggunakan teknik observasi, wawancara, dan dokumentasi. Teknik analisis data yang digunakan dalam penelitian ini yaitu analisis interaktif. Ada empat model komponen dalam penganalisisan data yaitu, pengumpulan data, reduksi data, penyajian data, dan penarikan kesimpulan. Penelitian ini menggunakan tiga teknik keabsahan data kualitatif yang meliputi uji kredibilitas, uji dependability, dan uji konfirmability. Tahap pengumpulan data merupakan mengolah data dengan cara memilah data yang diperlukan dalam penelitian. Tahap penarikan kesimpulan adalah tahap menafsirkan data penelitian yang kemudian dapat ditarik kesimpulan.

\section{TEMUAN DAN PEMBAHASAN}

Pembelajaran terkait dengan proses interaksi berbagai elemen yang ada dalam system Pendidikan tersebut terutama peserta didik dan guru. Begitu juga dengan system Pendidikan tinggi yang membutuhkan interaksi yang tepat antara dosen dan mahasiswa. Kegiatan pembelajaran dalam masa pandemi khususnya pada mahasiswa Pendidikan ekonomi Universitas Ekasakti cukup berbeda dengan kegiatan pembelajaran pada umumnya, dimana antara pendidik terutama dosen tidak bisa bertatap muka secara langsung. Demi keberlangsungan kegiatan pembelajaran tanpa terbatasi oleh pandemi maka kegiatan pembelajaran dialihkan kepada pembelajaran daring. Moore, Dickson-Deane, \& Galyen dalam (Firdaus, 2020) mengemukakan pendapat bahwa Pembelajaran daring adalah sebuah proses pembelajaran jarak jauh dengan bantuan akses media internet yang didalamnya mencangkup konektivitas, aksesibilitas, fleksibilitas, dan memungkinkan terjadinya beragam interaksi dalam proses belajar. Pemanfaatan teknolgi mengubah cara kegiatan pelaksanaan pembelajaran dari pembelajaran konvensional menjadi pembelajaran digital. Hal ini juga sesuai dengan tuntutan perkembangan zaman dan teknologi bahwa belajar bisa dimana saja dan kapan saja tanpa terbatas ruang dan waktu. Pembelajaran daring efektif mengatasi kegiatan belajar mengajar yang memungkinan pendidik serta peserta didik berinteraksi melalui kelas virtual yang memiliki akses tidak terbatas ruang serta waktu (Lusiani, 2021).

Proses pendidikan tinggi di tengah pandemi Covid-19 terus berusaha memaksimalkan sarana digital. Pelaksanaan kegiatan pembelajaran yang dilakukan pada Program Studi Pendidikan Ekonomi Universitas Ekasakti dalam masa pandemi ini menggunakan system pembelajaran daring dengan berbagai platform seperti whatapps group, google classroom, Edmodo, juga khusus menggunakan aplikasi kelas digital yang membantu memudahkan pelaksanaan kegiatan pembelajaran daring. Pihak universitas Ekasakti juga memberikan kebebasan dalam penggunaan berbagai media untuk menunjang perkuliahan secara daring serta efektifitas dan kenyamanan perkuliahan di masa pandemi covid-19.

Kegiatan pembelajaran daring juga meningkatkan kegiatan pembelajaran active learning dengan peningkatan pendekatan pembelajaran student centered learning. Dimana mahasiswa Pendidikan ekonomi lebih bisa mengaktulisasikan dirinya melalui pembelajaran daring. Dalam pembelajaran active learning dituntut mahasiswa lebih aktif dalam kegiatan pembelajaran, pembelajaran berpusat pada aktivitas mahasiswa. Disini dosen sebagai fasilitator, motivator, pengarah dan juga dapat sebagai perancang kegiatan pembelajaran yang dilakukan seperti apa. Melalui pembelajaran daring mahasiswa dapat mengembangkan kemampuannnya dalam penggunaan berbagai aplikasi pembelajaran seperti mahasiswa melalui kegiatan pembelajaran daring mampu membuat video pembelajaran yang menarik. Mahasiswa sebelumnya belum pernah membuat dan mempelajari bagaimana membuat video pembelajaran pada pembelajaran daring karena semua sudah tersaji secara langsung dikelas. Seperti pada wawancara yang dilakukan pada mahasiswa dimana mahasiswa karena tuntutan tugas akhirnya 
semangat untuk mempelajari hal baru terkait pembuatan video pembelajaran.

Kesuksesan kegiatan pembelajaran tidak bisa tergantung pada satu pihak saja seoerti dosen atau mahasiswa saja, tapi berkaitan dengan semua pihak yang terlibat dalam kegiatan pembelajaran. Begitu juga dengan kegiatan pembelajaran daring tidak akan berarti tanpa adanya komunikasi yang baik dan efektif antara dosen dan mahasiswa. Proses belajar mengajar yang efektif akan terbangun dari proses pembelajaran yang komunikatif. Pendekatan komunikatif adalah sistem pembelajaran yang menekankan pada aspek komunikasi, interaksi, dan mengembangkan kompetensi kebahasaan, serta keterampilan berbahasa (menyimak, membaca, menulis, berbicara) sebagai tujuan pembelajaran bahasa dan mengakui bahwa ada kaitannya dengan kegiatan komunikasi dalam kehidupan sehari-hari.

Berbagai manfaat serta kemudahan dapat ditemui dari pelaksanaan kegiatan pembelajaran daring. Dimana kegiatan pembelajaran tidak terbatas pada konteks waktu yang baku, kegiatan pembelajaran juga lebih fleksibel tergantung kepada kesepakatan antara dosen dan mahasiswa dalam kegiatan pembelajaran. Kelebihan pembelajaran daring, 1) Dapat diakses lebih mudah. 2) Biaya yang terjangkau. 3) Waktu belajar lebih fleksibel. 4) Wawasan yang lebih luas (Dewi \& Sadjiarto, 2021). Beberapa mahasiswa menyatakan puas dengan pembelajaran daring karena mereka dapat menghemat pengeluaran seperti kos, biaya hidup jauh dari orang tua, dapat kuliah sambal bekerja sehingga dapat menambah pendapatan karena perkuliahan lebih fleksibel. Walaupun kebanyakan mahasiswa menyatakan tidak puas dalam pelaksanaan perkuliahan daring.

Berdasarkan wawancara diperoleh bahwa mahasiswa lebih nyaman menggunakan aplikasi WhatApps Group dalam perkuliahan daring, hal ini karena lebih praktis dan respon yang diberikan cenderung lebih cepat dibandingkan melalui aplikasi lainnya. Senada dengan penelitian (Dewi \& Sadjiarto, 2021) yang menemukan bahwa WhatsApp dipilih karena dirasa paling efektif dan mudah untuk digunakan. Selain itu, Google Classroom juga merupakan aplikasi yang banyak digunakan untuk kegiatan perkuliahan. Google classroom dianggap lebih familiar dibandingkan dengan platform maupun aplikasi lain dalam pembelajaran daring. (Aji et al., 2020). Dengan pembelajaran daring siswa memiliki keleluasaan waktu belajar, dapat belajar kapanpun dan dimanapun. Siswa dapat berinteraksi dengan guru menggunakan beberapa aplikasi seperti classroom, video converence, telepon atau live chat, zoom maupun melalui whatsapp group.

Universitas Ekasakti-Akademi Akuntansi Indonesia (Unes-AAI Padang) dalam rangka adaptasi pada pembelajaran digital masa pandemi dan juga menyambut era new normal yang meluncurkan aplikasi "kelas digital" untuk menunjang perkuliahan daring. Kelas digital merupakan platform pembelajaran digital yang digunakan untuk melangsungkan proses pembelajaran di Universitas Ekasakti dan Akademi Akuntansi Indonesia. Hal ini menujukkan bahwa pandemi tidak menghambat kegiatan perkuliahan. Pemanfaatan aplikasi Kelas Digital sendiri menjadi opsi paling baik untuk dimaksimalkan. Rektor universitas ekasakti mengungkapkan Aplikasi Kelas Digital di pakai agar perkuliahan tetap berjalan. Bahkan dengan lebih simpel, fleksibel, dan mandiri.v Dengan kelas digital, para mahasiswa diharapkan tetap maksimal melahap setiap materi perkuliahan dari para pengajar atau dosen-dosen kita (Haluan, 2021).

Kelas digital adalah kelas virtual berbasis digital dalam proses perkuliahan. Aplikasi Kelas Digital sudah membantu mahasiswa dan dosen untuk melaksanakan pembelajaran yang nyaman dan mudah untuk semuanya. Universitas Ekasakti-Akademi Akuntansi Indonesia (Unes-AAI Padang) melakukan inovasi dalam perkuliahan saat era new normal. Kehadiran aplikasi kelas digital ini agar perkuliahan dapat dilakukan menjadi lebih simpel, fleksibel dan mandiri selama pandemi Covid-19. Sekaligus solusi bagi orangtua dan calon mahasiswa agar dapat berkuliah di masa pandemi Covid-19. Dalam aplikasi kelas digital tersebut, memungkinkan mahasiswa dan dosen melakukan proses belajar, dan bimbingan. Hingga pendokumentasian seluruh aktivitas Tri Dharma. Ini diterapkan seluruh program studi di Unes-AAI. Penggunaan aplikasi sederhana ini juga tidak menyedot kuota terlalu banyak. Karena platformnya ini mempunyai tagline Ilmu dalam Genggaman (Sevia, 2021)

Pengaplikasian Kelas Digital diharapkan mahasiswa dan dosen dapat melaksanakan aktivitas perkuliahan tanpa hambatan pandemi dan juga jarak jauh. Aplikasi mobile berbasis android yang disebut sebagai kelas digital diterapkan mulai tahun ajaran 2020/2021 dan diluncurkan agar proses perkuliah berjalan sesuai dengan penerapan adaptasi kebiasaan baru. Dengan demikian ke depan, mahasiswa akan belajar jarak jauh dengan memanfaatkan aplikasi mobile berbasis android.(Haluan, 2021). Berbagai kemudahan di peroleh dengan penggunaan aplikasi Kelas Digital ini dalam perkuliahan, terutama 
memudahkan mahasiswa dalam mengakses kegiatan perkuliahan karena tersedia dalam gadget masingmasing dan simple. Juga sebelum memulai perkuliahan ada pengingat dari aplikasi ini bahwa perkuliahan akan dimulai sehingga mahasiswa tidak lupa dan tidak terlambat dalam mengikuti perkuliahan. Juga berbagai fitur-fitur yang ditawarkan seperti kuis, tugas dan materi yang mudah di akses oleh mahasiswa dimana saja.

Proses kegiatan perkuliahan secara daring tentunya tidak terlepas dari berbagai problematika yang dihadapi termasuk juga dalam penggunakan platform Kelas Digital. Secara umum ditemui permasalahan dalam pembelajaran daring berdasarkan wawancara yang dilakukan kepada mahasiswa melalui google form ditemui bahwa kendala paling besar dalam pembelajaran daring adalah kendala jaringan yang tidak bagus hal ini dikarenakan rata-rata mahasiswa akibat pandemi memilih untuk pulang kampung sehingga terjadi keterbatasan akses untuk internet. Selain itu juga berkaitan dengan biaya atau kuota internet yang banyak tersedot sehingga membutuhkan pengeluaran ekstra bagi mahasiswa. Masalah lain yang ditemui yaitu mahasiswa merasa kurang puas dalam perkuliahan terkait dengan materi yang tidak dipahami, kesulitan untuk berdiskusi dan bertanya kepada dosen terkait dengan materi. Kekurangan pembelajaran daring yaitu 1) Adanya keterbatasan akses internet. 2) Kurangnya interaksi antara pendidik dengan peserta didik. 3) Adanya perbedaan terhadap pemahaman materi. 4) Kurangnya pengawasan dalam proses pembelajaran (Dewi \& Sadjiarto, 2021). Lebih lanjut (Firdaus, 2020) mengungkapkan mahasiswa kurang paham pengelolaan pembelajaran dalam mengikuti perkuliahan daring selama masa pandemic seperti kesiapan teknologi (smartphone), kesiapan fisik (tubuh yang sehat) dan kesiapan sumber belajar belum memiliki kesiapan mengakses internet (kuota internet mahal) dan mengoperasikan media pembelajaran seperti google classroom dan eLearning; mahasiwa belum memahami tata cara dalam melakukan pembelajaran daring. Dari sekian banyak kendala yang dialami oleh responden, terdapat tiga jenis hambatan yang paling banyak dialami responden selama perkuliahan daring, yakni kuota yang terbatas sebanyak $21,5 \%$, jaringan tidak stabil sebanyak $23,4 \%$ dan tugas yang menumpuk sebanyak 30,6\% (Jamaluddin et al., 2020)

Begitu juga dengan penggunaan aplikasi kelas digital sangat membantu dalam perkuliahan daring di masa pandemi ini. Walaupun dengan berbagai problema dan hambatan yang ditemui dalam pelaksanaannya. Permasalahan yang dihadapi umumnya sama dengan yang dihadapi terkait dengan pembelajaran secara daring. Platform Kelas Digital belum digunakan untuk semua tingkat mahasiswa. Platform ini baru digunakan untuk mahasiswa baru terutama mahasiswa semester 2. Kendala yang sering ditemui yaitu masih terkait dengan kendala jaringan yang kurang stabil sehingga sering menyebabkan mahasiswa gagal login dalam mengikuti perkuliahan, juga terkendala dalam absensi perkuliahan. Kemudian masih ada mahasiswa yang kurang bisa mengoperasikan platform Kelas Digital dengan baik seperti dalam mengunggah tugas, kuis dan lainnya.

Dalam pembelajaran jarak jauh ini tentunya mahasiswa wajib memiliki fasilitas atau alat pendukung kegiatan pembelajaran daring. Namun masih banyak mahasiswa yang belum mampu menyediakan perangkat pendukung seperti dalam perkuliahan banyak menggunakan berbagai aplikasi dan platform. Banyaknya aplikasi seperti zoom, google classroom, google meet, Edmodo, WA Group dan lainnya juga menjadi kendala tersendiri yang menyebabkan memory Handphone penuh sehingga juga menghambat kegiatan pembelajaran daring. Disisi lain mahasiswa merasa belum mampu belajar secara mandiri, dan terdapat ketidakpuasan mahasiswa dalam menerima materi pembelajaran. Dimana mahasiswa kurang mendapat penjelasan terkait materi perkuliahan sehingga sulit memahami materi yang disampikan. Untuk berdiskusi pun juga terbatas. Faktor lainnya yaitu masalah komunikasi juga memiliki problematika, penjelasan guru terkadang kurang detail dan jelas (Harahap et al., 2021).

Berdasarkan penelitian tersebut maka perguruan tinggi perlu meninjau kembali metode pembelajaran jarak jauh yang ada saat ini, dimana pembelajaran daring memiliki aspek positif dan negative. dan juga perlu memperkuat literasi digital baik mahasiswa maupun dosen. Jadi solusi dalam hal ini bermakna Pembelajaran daring memiliki sisi positif dan negatif. Pembelajaran daring sangat memudahkan mahasiswa dan dosen untuk melakukan interaksi pembelajaran kendati hanya melalui dunia virtualengelolaan dalam proses pembelajaran secara daring juga penting terkait dengan akses internet dan pengiriman tugas yang harus tepat waktu.

Solusi yang tepat bagi berbagai permasalahan yang muncul dalam implementasi pembelajaran luring menjadi daring di masa pandemi ini tentunya diharapkan dapat meningkatkan kesuksesan pembelajaran dan juga perkuliahan yang dilaksanakan. Salah satu upaya yang dapat dilakukan 
untuk mengatasi berbagai persoalan tersebut yaitu pengelolaan pembelajaran yang baik melalui komunikasi dan interaksi yang lebih intensif antara dosen dan mahasiswa dalam perkuliahan daring. Mengoptimalkan komunikasi menjadi point penting demi kelancaran dan kesuksesan perkuliahan daring karena banyaknya mahasiswa yang tidak paham dengan materi yang disampaikan juga cenderung materi kurang jelas dan kurang dipahami oleh mahasiswa. Literasi digital juga perlu ditingkatkan tidak hanya dosen tetapi juga mahasiswa untuk meningkatkan kualitas pembelajaran daring terutama dalam penggunaan berbagai fitur teknologi, aplikasi dan platform pembelajaran terutama juga pada Platform Kelas Digital. Dan juga kendala-kendala teknis seperti susahnya sinyal dan jaringan untuk pembelajaran online hendaknya mampu di minimalisir dengan mencari tempat dan posisi yang tepat untuk mendapatkan sinyal yang baik untuk kelancaran perkuliahan daring.

\section{SIMPULAN}

Berdasarkan hasil dari penelitian dan pembahasan yang telah disampaikan mengenai implementasi pembelajaran luring menjadi daring pada masa pandemi bagi mahasiswa Pendidikan ekonomi Universitas Ekasakti disimpulkan bahwa pelaksanaan implementasi pembelajaran daring ini sudah berjalan dengan baik, namun ada beberapa kendala yang dihadapi terkait dalam hal pelaksanaan kegiatan perkuliahan daring yaitu mahasiswa merasa kurang puas dalam perkuliahan terkait dengan materi yang tidak dipahami, kesulitan untuk berdiskusi dan bertanya kepada dosen terkait dengan materi, kendala teknis seperti jaringan yang buruk dan mahalnya kouta. Secara khusus kendala yang ditemui dalam platfom Kelas Digital yaitu kesulitan mahasiswa dalam melakukan login mengakibatkan mahasiswa tidak bisa mengikuti perkuliahan melalui Kelas Digital.

Berdasarkan hasil penelitian tersebut, ada beberapa keterbatasan dalam penelitian ini diantaranya analisis yang kurang mendalam penerapan pembelajaran daring khususnya menggunakan platform Kelas Digital. Pada peneliti selanjutnya diharapkan untuk melakukan penelitian yang lebih akurat dan mendalam mengenai perencanaan dan pelaksanaan pembelajaran daring menggunakan platform Kelas Digital sehingga hasil penelitian yang didapat lebih luas dan terinci,

\section{DAFTAR PUSTAKA}

Aji, W., Dewi, F., Kristen, U., \& Wacana, S. (2020). DAMPAK COVID-19 TERHADAP IMPLEMENTASI PEMBELAJARAN DARING DI SEKOLAH DASAR. Jurnal Ilmu Pendidikan, 2(1). https://edukatif.org/index.php/edukatif/index

Chandra, F., Fitriani, N., \& Enrekang, U. M. (2021). Proses Pembelajaran Selama Masa Pandami Covid 19. Maspul Journal of Community Empowerment, 3, 21-26.

Dewi, T. A. P., \& Sadjiarto, A. (2021). Pelaksanaan Pembelajaran Daring Pada Masa Pandemi Covid19. Jurnal Basicedu, 5(4), 1909-1917.

Eka p, D. P. (2021). Implementasi Pembelajaran Daring dan Luring Saat Pandemi Covid 19. Edugama: Jurnal Kependidikan Dan Sosial Keagamaan, 6(1), 111-130. https://doi.org/10.32923/edugama.v6i1.1326

Firdaus, F. (2020). Implementasi Dan Hambatan Pada Pembelajaran Daring Di Masa Pandemi Covid 19. Utile: Jurnal Kependidikan, 6(2), 220-225. https://doi.org/10.37150/jut.v6i2.1009

Haluan. (2021). Adaptasi Kebiasaan Baru, Pembelajaran Unes-AAI Padang Andalkan Aplikasi Kelas Digital. November.

Handayani, Febri, H., \& Surahman, S. (2021). Implementasi Pembelajaran Daring dan Luring bagi. 4(02), 103-116.

Harahap, S. A., Dimyati, D., \& Purwanta, E. (2021). Problematika Pembelajaran Daring dan Luring Anak Usia Dini bagi Guru dan Orang tua di Masa Pandemi Covid 19. Jurnal Obsesi : Jurnal Pendidikan Anak Usia Dini, 5(2), 1825-1836. https://doi.org/10.31004/obsesi.v5i2.1013

Haryadi, R., \& Selviani, F. (2021). PROBLEMATIKA PEMBELAJARAN DARING DI MASA PANDEMI COVID-19 Pendidikan Fisika, Universitas Sultan Ageng Tirtayasa Email : rudiharyadi@untirta.ac.id Email : selvianifitria28@gmail.com AoEJ : AoEJ: Academy of Education Journal, 12, 254-261.

Ika. (2020). Membedah Tantangan Pembelajaran Daring Covid-19. Www.Ugm.Ac.Id, 2020-2021. https://ugm.ac.id/id/berita/19552-membedahtantangan-pembelajaran-daring-di-tengah-pandemicovid-19

Lusiani. (2021). EDUKATIF : JURNAL ILMU PENDIDIKAN Analisis Pelaksanaan Pembelajaran Online dalam Masa Pandemi Covid-19 berdasarkan Persepsi Guru Sekolah Menengah Kejuruan. Edukatif, 3(5), 2586-2593.

Muhammad, H. (2020). Menyiapkan Pembelajaran di Masa Pandemi: Tantangan dan Peluang. Kementerian Pendidikan Dan Kebudayaan, 1-22.

Padek. (2021). PPKM Darurat Diperpanjang Hingga 25 Juli, Boleh Makan di.

Pratama, R. E., \& Mulyati, S. (2020). Pembelajaran Daring dan Luring pada Masa Pandemi Covid-19. Gagasan Pendidikan Indonesia, 1(2), 49. https://doi.org/10.30870/gpi.v1i2.9405 
Gumanti, D., Teza, D.D., \& Respita'R. | Analisis Implementasi Pembelajaran Luring Menjadi Daring

Putria, H., Maula, L. H., \& Uswatun, D. A. (2020). Analisis Proses Pembelajaran dalam Jaringan (DARING) Masa Pandemi Covid- 19 Pada Guru Sekolah Dasar. Jurnal Basicedu, 4(4), 861-870. https://doi.org/10.31004/basicedu.v4i4.460

Sadikin, A., \& Hamidah, A. (2020). Pembelajaran Daring di Tengah Wabah Covid-19. Biodik, 6(2), 109-119. https://doi.org/10.22437/bio.v6i2.9759

Sevia, N. (2021). Tahun Ajaran Baru, Unes-AAI

Terapkan Kuliah Digital. Tahun Ajaran Baru, Unes AAI Terapka $n$ KUliah Digital. 